\title{
Euroscepticism and populism in Hungary: The analysis of the prime minister's discourse
}

\author{
Adela Danaj \\ Doctoral School for Safety Sciences of Obuda University \\ Hungary \\ adela.danaj@uet.edu.al
}

\section{Kornélia Lazányi}

Keleti Faculty of Business and Mangement of Obuda University

Hungary

lazanyi.komelia@kgk.uni-obuda.bu

\section{Svitlana Bilan}

Centre of Sociological Research

Poland

office@csr-pub.eu

Abstract. Migration flows, distrust in European institutions and transnational governmental ineffectiveness and low economic performance have become a favorable ground for the so-called populist governments that are widely using Eurosceptic and populist rhetoric today. Voters perceive traditional elite as powerless in front of contemporary socioeconomic problems. Consequently, populist leaders, at the regional level, have opposed the policies of European institutions. Populism has developed and become part of every European Union (EU) member state and today is gathering more and more Eurosceptic components too. This study is to investigate what message the Prime Minister of Hungary is conveying to his voters. In order to realize this primary objective, we will observe how the political discourse changed over time and how widely populist and eurosceptical rhetoric is present in today's political discourse. In the first part of this study we briefly review the literature on populism and Euroscepticism to frame the articulations of different populist and various eurosceptical claims. Our goal is to identify, through thematic analysis, which concepts related to the European Union get more attention at the institutional level. We expect to find a significant occurrence of populist and Eurosceptical elements in the Prime Minister's discourse.

Keywords: Euroscepticism, institutional trust, populism, political discourse, rhetoric, text analysis. 
JEL Classification: A13, A14, D7

\section{INTRODUCTION AND THEORETICAL FRAMEWORK}

Financial insecurity, distrust in institutions, governmental ineffectiveness and low economic performance have become today a favorable ground for the populist parties to campaign against. In case of low institutional trust voters perceive traditional elites as being powerless in front of numerous contemporary socioeconomic problems (Mudde, 2015).

Since institutional trust is a dynamic relationship of the individual and the institution relevant to the life of the individual, the scope of institutions to be trusted varies from individual to individual (Hurley et al., 2013). The primary institutions to be considered in this regard are police, the legal system overall, healthcare and education system and finally the groups (institutions) involved in policy-making (Rousseau et al., 1998). In this latter group some individuals only consider local and national institutions, others, on the other hand, include here the institutions of the European Union as well.

Although trust - at least to a certain extent - is mostly a personal feature (some people are rather trusting while others are not so easy to trust), the level of trust is also influenced by individual experiences and his/her social surrounding (Hudson, 2006). When there is a lack of direct personal experience, stories of others, rumors and official broadcasts are much more appreciated (Mischler \& Rose, 2001). In such cases the trend and disposition of political discourse of the actual political elite can be determining. While institutional trust is strongly related to power dynamics, including (but not limited to) forms of power (social and political), it has major implications regarding the power base of the political elite as well (Bachmann, 2001).

Institutional trust is often expressed through value judgment (Shockley et al., 2015). The nature of the relationship can be qualified as supportive, neutral or opposing. The magnitude of institutional trust however is very hard to quantify. Same as all individual inclinations it does not only differ from individual to individual, but is heavily influenced by the actual mood, time and personal (direct or indirect) experiences (Sharma \& Gursoy, 2017).

Institutional trust gains extreme importance in the light of the European integration process, which according to Luigi Zingales - is often placing the interest of one country against the interest of another, or in occasions against that of the whole European Union. The situation is even more tricky, if we consider the Eurosystem for which the countries gave up their monetary sovereignty, which has led to a certain discontent towards the political system, thus feeding the rhetoric of populist parties and undermining democracies and the European integration project as such (2014).

Consequently, populist parties, at the regional level, have been opposing the policies of European institutions, creating, or fostering mistrust in the institutions of the European Union. Thus, Eurosceptic discourse, using a narrative with a realistic background, has become a crucial component of campaigning for rising populist parties. As argued by Taggart and Szczerbiak, Euroscepticism has developed to become part of every European Union (EU) member party system (2002:9), while sometimes Euroscepticism has also elements of populism in it (Taggart, 2002:69). As it has been many times argued that in Hungary (Enyedy, 2015:244) and in Poland populism may take place as a governmental force. Moreover, as these two abovementioned cases show, the EU international constraints can be easily bypassed for a certain amount of time, undermining liberal democracy (244: 2015) and slowing down the EU integration process.

Populism can be defined in terms of ideology but is also conceived as a political strategy for certain leaders to get power and win (Weyland, 2001). Populism can be seen as an ideology and as a political strategy, but not necessarily these two go together (Kiersi, 2015; Bilan \& Demkiv, 2017). 
The purpose of this study is to identify through computer-assisted thematic analysis with instrumental approach, the discursive pattern which combines Euroscepticism (lack of trust in European institutions) and the populist approach. More specifically, this study wants to investigate what prevails in the message that the acting Prime Minister is conveying to Hungarian voters.

\section{METHODOLOGY}

In order to investigate what message the Prime Ministry conveys to his voters regarding the European Union, and especially whether to trust the Euro itself, interviews by the Hungarian Prime Minister since 2012 has been be used. Only interviews in English that appeared on the government's website have been analyzed (Kormány. hu, 2016). A sample of thirty 30 interviews which cover the period from 2012 to 2016 has been used. The selection of the period has been made in accordance with the goal of the research. During this period Viktor Orban was the Hungarian Prime Minister and in the meanwhile he was campaign for the Parliamentary elections of 2014.

The analysis focused particularly on 2014 and 2015 and observe the changes of the themes before and after the elections. We decided to analyze interviews instead of speeches and party manifesto because populist leaders tend to have different approach and discourse in line with the composition of the audience. Speeches are usually consciously prearranged, while interviews should be more unpremeditated and spontaneous.

To conduct the study quantitative text analysis with instrumental approach was used to measure populism and Euroscepticism in the leader's discourse. Instrumental quantitative text analysis was proposed because it allows to treat large scale of texts as data in form of words and not as a discourse to be interpreted. Moreover, it can assure sufficient reliability and it is systematic, hence enables comparison over time and space, and circumvents the possible subjectivity of coders, since no human coder is involved. In order to conduct this study, a dictionary-based approach was followed.

Dictionary based approach is the method in which a computer allocates text unit to an a priori or a posteriori defined coding scheme. Due to the nature of populism and Euroscepticism the dictionary based method seemed the most appropriate, since it left to the researchers more freedom to adapt the operationalization to the theoretical framework. The dictionary categories which we decided to use (e.g. immigration, anti-elitism, exclusionism, Euroscepticism) are a priori reasoning (a more detailed description of the dictionary of the computer-based quantitative text analysis is provided in Table 1. based on Interviews of Primer Minister from 2012 and 2015 N= 30 Source: Hungarian Government Website). In order to create our categories, reference documents, article and literature about populism and Euroscepticism has been consulted. However, we are well aware that a dictionary to detect populism and Euroscepticism from the Hungarian leader discourse might also be implemented with other categories which might come from other interpretation of the theoretical background of populism and Euroscepticism.

In order to build the dictionary categories of populism we referred to some core concepts of the ideology which we translated in the categories. The categories' themes and concepts come partially from the theory and partially from the reality. The dictionary has been build taking into account the frequent occurrence in the data set and some ideas we had during the research process. For instance, the economic variable has been added at the end, as it is -according to our belief - a component of populism and it is becoming more and more tied to Eurosceptical argument. Since populism is based on the idea of democracy and anti-elitism opposing whom are above, in the category people-centrism and elitism, words such as referenda, direct, majority are used as level of measurement of populism. We decided to add a category which we called self-references since populist discourse is usually driven by the charismatic role of the leader. In this category words such as I, me, us, myself, my, mine, are included to measure populism. Populism is 
also based on the exclusive and anti- immigration argument. Therefore, the category Exclusionism and Migration has been created and words such as asylum seekers, fence, immigration, terrorism are indicators of populism. The last two categories to measure populism are Protectionism and Conservatives where words such as multinational, foreign control, monopole, state intervention, family, Christianity, values, nation are level of measurement of populism. The last two categories have been created to measure Eurosceptical concepts in the populist discourse. In order to identify the Eurosceptical elements a category with negative instance has been created, words such as Brussellism, burocrats, forcing homogeneity, national sphere, Europe unable serve as level of measurement for Euroscepticism. As a cofounding variable we decide to create a category which embeds simple references to European Union. This category contains words such as European Parliament, Lisbon treaty.

Table 1

Dictionary for coding

\begin{tabular}{|c|}
\hline SM \\
\hline Indicators of people centric and elitism expression. \\
\hline 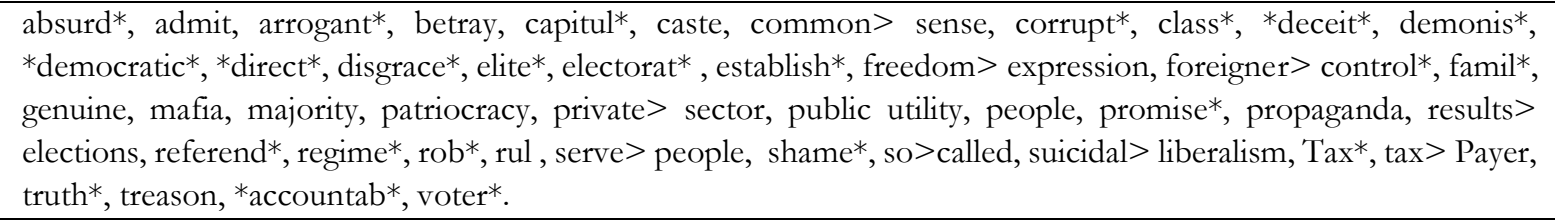 \\
\hline Indicators of exclusionism and anti - immigration policy. \\
\hline $\begin{array}{l}\text { Anti }>\text { terrorism, asylum }>\text { sekeer, belongs }>\text { Europeans, Black*, border }>\text { control*, crime*, Increase }>\text { crimes, } \\
\text { dishonest }>\text { solidarity, fence*, }{ }^{*} \text { lega } * \text {, imam, immigration }>\text { bad, muslim*, migration }>\text { affecting, }{ }^{*} \text { migra*, } \\
\text { invasion*, refugee*, slam, stop }>\text { migration, jeopardize }>\text { livelihood* }\end{array}$ \\
\hline CONSERVATIVISM \\
\hline Indicators of Christian and Nationalistic values \\
\hline $\begin{array}{l}\text { Belie*, blood, believe*, Church, Christian*, christian }>\text { culture, }{ }^{*} \text { compet* }^{*} \text {, custom*, famil*, God, ethnic }> \\
\text { foundation, role, sovereignty, defend }>\text { Hungary, *dependent*, occup*, pride, separ*, state, strength }>\text { nation, } \\
\text { strong }>\text { reform, transcend }>\text { nation Value* }\end{array}$ \\
\hline Indicators of protectionism as economic policy \\
\hline $\begin{array}{l}\text { Capital }{ }^{*} \text {, commercial, eneterprise*, employ*, foreign }>\text { competition, foreigner }>\text { control, foreigner }>\text { owned, } \\
\text { import*, internationalism, local }>\text { business, market }>\text { regulation, multinational, monopol, quota, state }>\text { own, state }> \\
\text { intervention, state }>\text { regulation, subsidies, ownership, tariff, tax }>\text { cut, trade }\end{array}$ \\
\hline EUROSCEPTICISM \\
\hline Indicators which are used to identify the occurrence of the European Union topic as such. \\
\hline $\begin{array}{l}\text { Agreement*, Border*, Brussels, Commission, Council, ECB, European }>\text { Parliament, EU, Eurozone, } \\
\text { European }>\text { crises, European }>\text { Union, Friends }>\text { Cohesion, Lisbon }>\text { treaty Maastricht }>\text { treaty, } \\
\text { chengen }>\text { Agreement, treat*, Troika, Junker, Tusk }\end{array}$ \\
\hline $\begin{array}{l}\text { Indicators which measures the occurrence of negative aspects and expression about The European } \\
\text { Union and the European Integration process }\end{array}$ \\
\hline $\begin{array}{l}\text { Europe }>\text { not able, advantage*, Alert*, Brussels }>\text { attempting, Brussels }>\text { force, Brussels }>\text { tone, Brussellism, } \\
\text { bureaucrat, battle }>\text { Brussels, Christian }>\text { identity , capable, clear, community }>\text { state, community }>\text { nation, } \\
\text { competent*, continuous }>\text { attempt, crise }>\text { zone, defend }>\text { Hungary, democratic, domestic, Europe }>\text { unable, } \\
\text { Europe }>\text { divided, European }>\text { beaurocrat, European }>\text { crises, European }>\text { trade, Eurobabble, european }>\text { people, } \\
\text { failure }>\text { comply, foundation, forcing }>\text { homogeneity, fraud }>\text { border, full }>\text { blooded, growth, Hungarian }>\text { interest, } \\
\text { Hungar*, imposing }>\text { rules, inadvertent }>\text { effect*, lack }>\text { unity, lacking }>\text { Brussels, management }>\text { of, member, } \\
\text { nation, national }>\text { responsibility, national }>\text { sovereignty, national }>\text { sphere non }>\text { existent, norm*, power*, } \\
\text { practice }>\text { contradicts, practice }>\text { Brussells, pressure, prevent }>\text { to, prospective*, provision*, rewriting }>\text { border, } \\
\text { root*, sanctions }>\text { against, reduce }>\text { authority, undermine }>\text { sovereignty, sphere }>\text { authority, spiritual }\end{array}$ \\
\hline
\end{tabular}


Once the code scheme has been finalised the second step has been to use the open software Spitta to identify how many words of the dictionary where present in the interviews. Previously, the interviews have been coded by hand into units of analysis. (The unit of analysis is a clause, thus a part of a sentence with its own inflected verb and associated object and subject.) The total number of observations (the unit of analysis) was in total 6866. The outcome that has been obtained by the results of the software Spitta being statistically analyzed by the software R - Studio.

\section{EMPIRICAL RESULTS AND DISCUSSION}

According with the descriptive statistics, the dictionary covers a substantive number of words which appears in the interviews released by the Prime Minister.

Table 2

Frequencies of various items $(\mathrm{N}=6866)$

\begin{tabular}{|c|c|c|c|c|c|c|c|}
\hline & 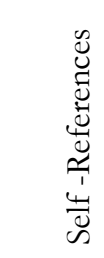 & 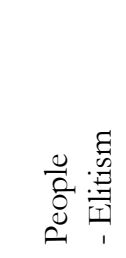 & 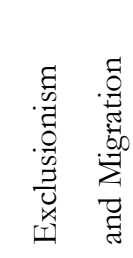 & 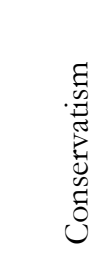 & 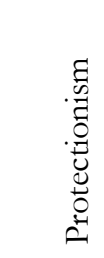 & 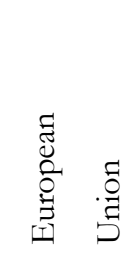 & 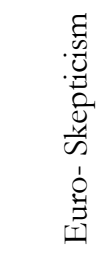 \\
\hline Frequency & 3488 & 910 & 367 & 509 & 251 & 546 & 1313 \\
\hline Ratio (\%) & 51.1 & 13 & 5.3 & 7.3 & 3.6 & 8.9 & 19.12 \\
\hline
\end{tabular}

Source: own compilation

As we were expecting the Self-reference variable covers a significant part of the interviews (51\%), although this is not a substantive information, due to the facts that the category englobes subjects and pronouns and has been created to control this kind of data. However, it shows a significant predominance in the entire sample. More interesting for the purpose of this study is the frequency of the people centric and euro - skeptical discourse. As we were expecting, one of the main component of the populist discourse, People Centrism and Elitism have close frequencies to the Eurosceptical rhetoric (13\%- 19\%). However, the Eurosceptic concepts seem to prevails. Moreover, the variable People-Centric Elitism, Exclusionism, Conservatism, Protectionism cover in total $29 \%$ of the data.

Beside the observation of the frequency in the entire sample, a second analysis has been conducted. Due to the small sample it is not possible to compare those categories over time. In the data set, years such as 2012 and 2016 are purely covered respect 2014 and 2015. However, it is possible to attempt a meaningful comparison between 2014 and 2015, which might be improved in the future enlarging the sample and collecting interviews over a greater time series.

In 2014 Parliamentary elections took place in Hungary so we decided to observe how the discourse changed from 2014 to 2015. Specifically, we wanted like to observe if the concepts highlighted in the dictionary increased or changed after this crucial year. This comparison is interesting because it makes possible to identify which is the tendency and the direction of the Prime Minister.

The new sample including 24 interviews, allows as to do compare 2014 and 2015. Moreover, the number of interviews in the two years doesn't differ significantly (2014 = 9 interviews, $2015=15)$ and it is the best sample we can aggregate from the data set. In order to compare the variable of interested over the 
2014 to 2015. We create a subset and the new sample decreased. The number of observation (recording unit) are 5506. We observed the frequencies and occurrence of the words in each recording unit of the interviews which took place in 2014 and 2015. We divided it in two scales. Afterwards, we compared the occurrence of the two scores over the 2014 and 2015. For instance, in Table 2.1 Occurrence $1-3$ counts all the observations where the words of the dictionary occur in a recording unit of analysis one, two or three times. Occurrence $4-5$ counts the recording unit where the words of the dictionary occurs 4 and 5 times. In tables $2.3,2.4,2.5$, due to the fact that the maximum values in the descriptive statistics was 7 , the same number has been used as maximum score in a recording unit.

\subsection{Populist Rhetoric}

The results (Figures 1-5) show that after the Parliamentary election in 2014 the occurrence of words which are categorized as populist increased over time. The results show that theme such as People centric and elitism, self-references and exclusionism and anti-immigration rhetoric have a tendency to increase substantially.

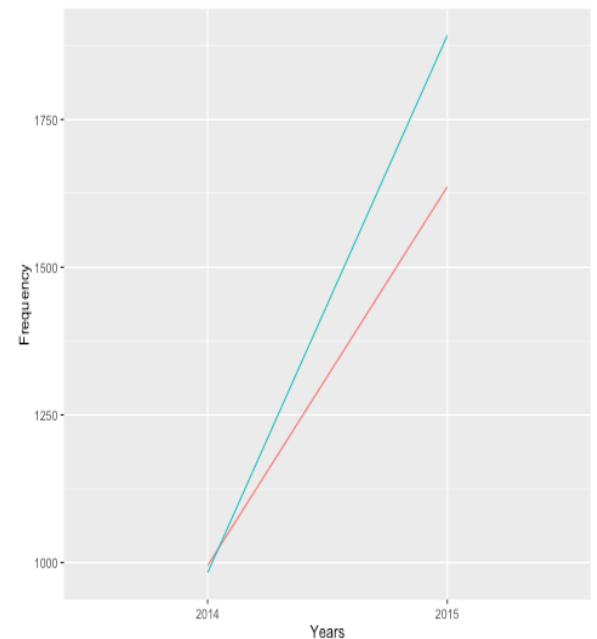

Figure 1. Self-References

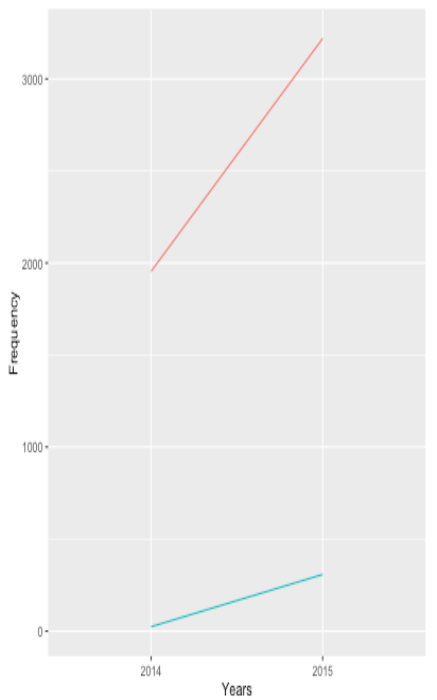

Figure 3. Exclusionism and Anti- Migration

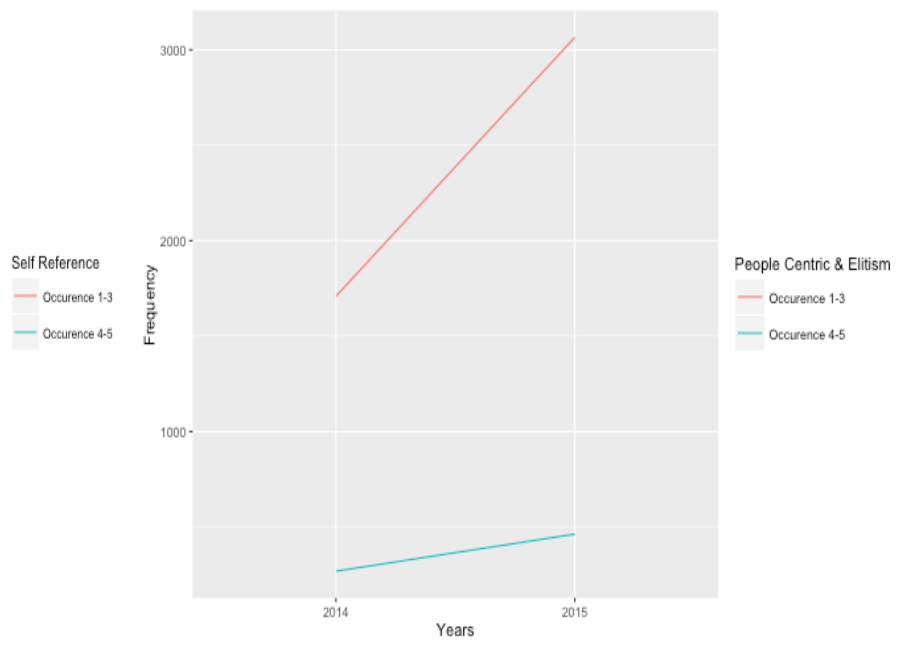

Figure 2. People Centric \& Elitism

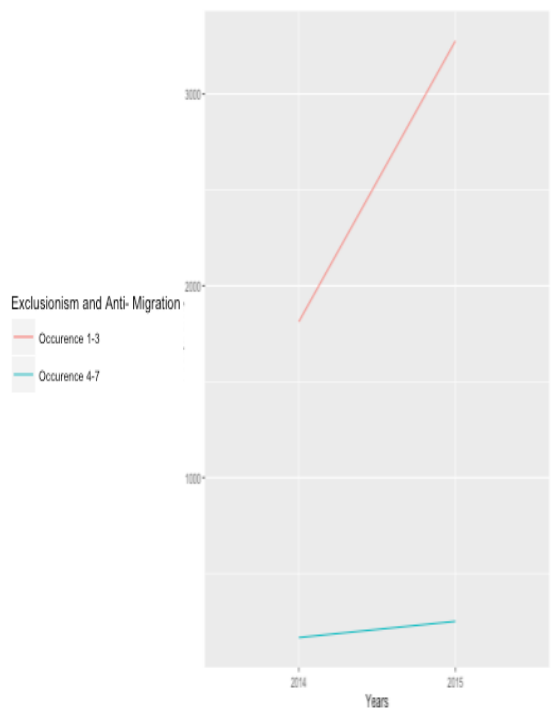

Figure 4. Conservatism

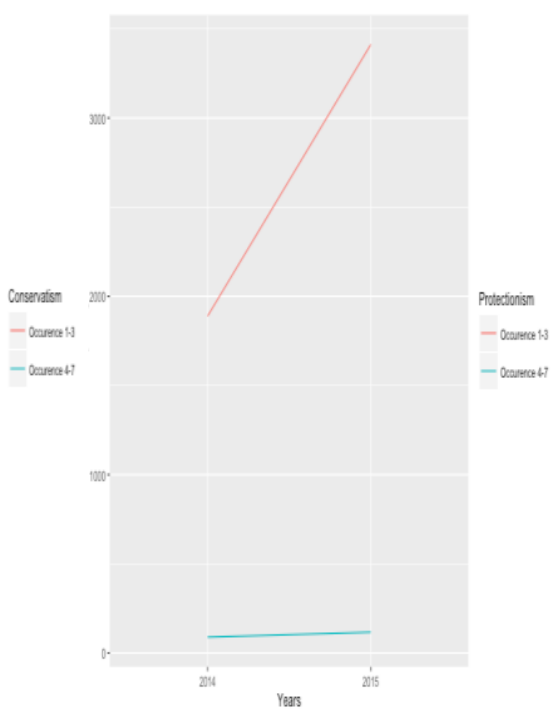

Figure 5. Protectionism 


\subsection{Europe and Euro- Skepticism}

The results (Figures 6-7) show that also the Euro-Skeptic rhetoric has a general tendency to increase between 2014 and 2015. The substantive observation which has to be made is that negative rhetoric seems to prevail the general talk about European Union.

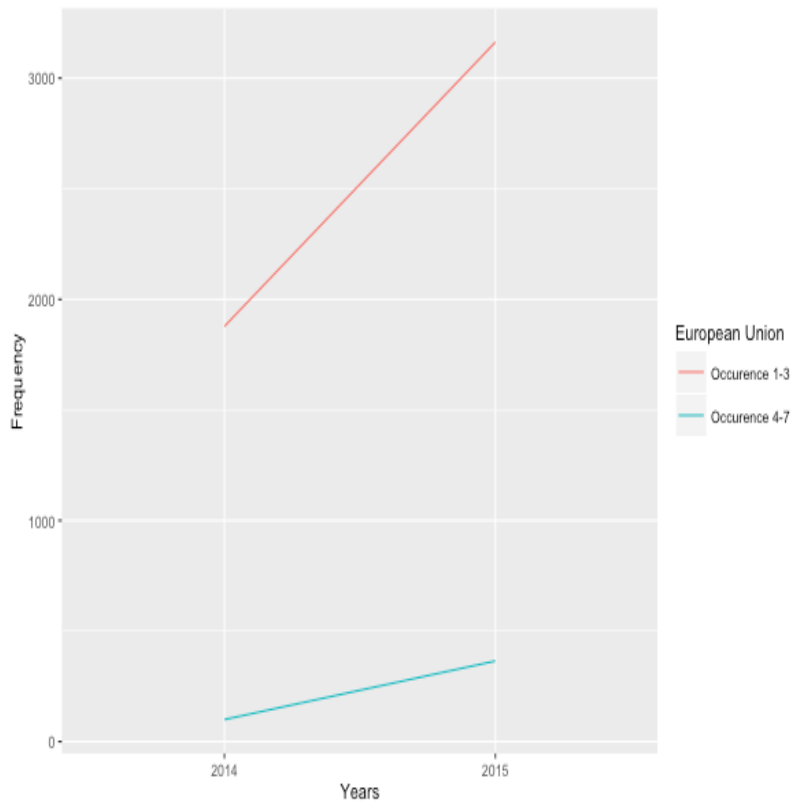

Figure 6. European Union

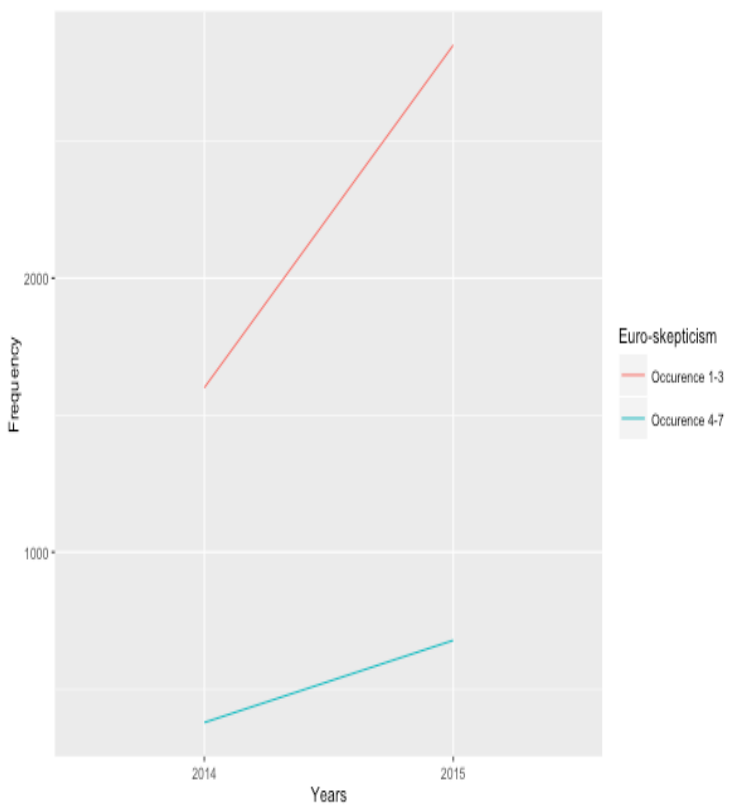

Figure 7. Euro- skepticism

\subsection{Validity of the method}

In order to assess the validity of the quantitative thematic analysis with instrumental approach I checked through the literature available about populism and Euroscepticism the content validity. Specifically, we verified that my themes and search entry correspond to the general conceptualization and reflect the general agreement on the real meaning of the two phenomena of interest.

Quantitative text analysis does not involve human coders so the risk of misinterpretation and mistake is reduced.

\section{CONCLUSION}

Measure populism and Euroscepticism it is not an easy task. Literature is quite divided on which method is the most appropriate to measure such a phenomenon. First, the literature disagrees on the definition of populism. Second, Euroscepticism is changing is meaning and it seems to be part of the populist rhetoric, or the opposite. Therefore, we argue, the two phenomena should not be observed and addressed separately.

This research is an attempt to show that, this can be done through quantitative text analysis for several reasons: thanks to the computerization of the process, a big amount of text can be analyzed across European countries, such as social media, newspapers, elite speeches, interviews, institutional material, allowing a comparison across countries. Moreover, the analysis is less costly then the classical content analysis and less time consuming. The limit of quantitative thematic is manly related to the dictionary. Since populism and euro skepticism are strongly related to the perception of the citizens consequently the strategic political populist discourse might be built on the cultural dimension. Therefore, the same categories and concepts might be interpreted differently by different researcher. To overcome this concern further methodological 
study focusing on populism should apply modality analysis which is a semantic analysis methodology to investigate how people intentions are discursively constructed. Since this method is based on the theoretical basis that people motivate themselves and others by persuading them self that their actions are possible, impossible, inevitable or contingent (Popping, 2009:245), we believe that this study might be implemented in the future, analyzing populism and euro- skepticism through modality analysis.

\section{ACKNOWLEDGEMENT}

The authors are thankful to the Hungarian Ministry of Human Resources for financing this research in the frame of the New National Excellence Program.

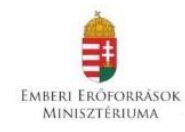

\section{REFERENCES}

Bachmann, R. (2001). Trust, power and control in trans-organizational relations. Organization studies, 22(2), $337-365$.

Bilan, Y., Demkiv, O. (2017). On the threshold of the 'union of closed doors': A social portrait of Ukrainian eurooptimists and Eurosceptics. Monitoring Obshchestvennogo Mneniya: Ekonomichekie i Sotsial'nye Peremeny, 139(3), 103-115.

Enyedi, Z. (2015). Plebeians, citoyens and aristocrats or where is the bottom of bottom-up? The case of Hungary. European populism in the shadow of the great recession. Studies in European political science, 235-250.

Hudson, J. (2006). Institutional trust and subjective well-being across the EU. Kyklos, 59(1), 43-62.

Hurley, R.F., Gillespie, N., Ferrin, D.F. \& Dietz, G. (2013). Designing Trustworthy organizations. Sloan Management Review, 54(4), 75-82.

Kormány.hu (2016). Retrieved February2, 2016 from http://www.kormany.hu/en/the-prime-minister/the-primeminister-s-speeches

Kriesi, H., \& Pappas, T. S. (Eds.). (2015). European populism in the shadow of the great recession. Colchester: Ecpr Press.

Mishler, W., \& Rose, R. (2001). What are the origins of political trust? Testing institutional and cultural theories in post-communist societies. Comparative political studies, 34(1), 30-62.

Mudde, C. (2015). Populism in Europe: a primer. Open Democracy, 12.

Popping, R., \& Roberts, C. W. (2009). Coding issues in modality analysis. Field Methods, 21(3), 244-264.

Rousseau, D. M., Sitkin, S. B., Burt, R. S., \& Camerer, C. (1998). Not so different after all: A cross-discipline view of trust. Academy of management review, 23(3), 393-404.

Sharma, B., \& Gursoy, D. (2017). Investigation of demographic difference on the local communities'perceptions of emotions, trust, attachment, and support for the FIFA Brazil world cup. In 7th Advances In Hospitality \& Tourism Marketing \& Management (Ahtmm) Conference (P. 79).

Shockley, E., Neal, T. M., PytlikZillig, L. M., \& Bornstein, B. H. (Eds.). (2015). Interdisciplinary perspectives on trust: Towards theoretical and methodological integration. Springer.

Taggart, P. (2002). Populism and the pathology of representative politics. In Democracies and the populist challenge (pp. $62-$ 80). Palgrave Macmillan, London. Taggart, Paul, and Szczerbiak. Aleks. 2002. The party politics of Euroscepticism in EU member and candidate states. Sussex: Sussex European Institute.

Weber, R. P. (1990). Basic content analysis (No. 49). Sage.

Weyland, K. (2001). Clarifying a contested concept: Populism in the study of Latin American politics. Comparative politics, 1-22.

Zingales, L. (2014). A capitalism for the people: Recapturing the lost genius of American prosperity. Basic books. 